\title{
The role of long non-coding RNA (IncRNA) in the development of ovarian cancer
}

Rola długich niekodujących RNA (IncRNA) w raku jajnika

Dietetics graduate, Department of Human Nutrition and Hygiene, Poznań University of Life Sciences, Poznań, Poland

Correspondence: Mgr Dorota Gumiela, Kołobrzeska 2a/4, 78-400 Szzzecinek, Poland, e-mail: dorota.gumiela@wp.pl

Absolwentka kierunku dietetyka, Wydział Nauk o Żywności i Żywieniu, Uniwersytet Przyrodniczy w Poznaniu, Poznań, Polska

Adres do korespondencji: Mgr Dorota Gumiela, ul. Kołobrzeska 2a/4, 78-400 Szzzecinek, e-mail: dorota.gumiela@wp.pl

Abstract The aim of this study was to review research on the role of long non-coding RNA (lncRNA) in ovarian cancer. This article analyses studies on the effect of increased lncRNA expression on the size of ovarian cancer and the incidence of metastasis. The review covers a period from October 15, 2018 to August 22, 2020, and comprises 23 studies in which a total of 1,580 women with ovarian cancer participated, and an undetermined number of control groups where healthy tissue samples were collected. A review of the studies indicates that increased lncRNA expression is associated with elevated ovarian cancer size and metastatic risk. The most studied lncRNA include HOTAIR, CCAT2, GAS5, MALAT-1, UCA1. Studies assessing the expression levels of HOTAIR IncRNA and CCAT2 in normal and cancer tissue showed varying levels of expression in studies of different authors, which indicates that the expression of the same lncRNA may vary individually or is a result of study errors.

Keywords: lncRNA, ovarian cancer, expression, FIGO

Streszczenie Celem pracy był przegląd badań dotyczących oceny roli długiego, niekodującego RNA (long non-coding RNA, lncRNA) w raku jajnika. W artykule dokonano przeglądu badań dotyczących wpływu zwiększonej ekspresji lncRNA na rozmiar raka jajnika i występowanie przerzutów. Przeglądu badań dokonano w okresie od 15 października 2018 do 22 sierpnia 2020 roku. W przeglądzie uwzględniono 23 badania, w których łącznie wzięło udział 1580 kobiet z rakiem jajnika oraz nieokreślona liczba osób z grup kontrolnych, od których pobrano zdrowe tkanki. Przegląd badań wskazuje, że zwiększona ekspresja lncRNA jest związana ze zwiększonym rozmiarem raka jajnika oraz przerzutami. Najczęściej badane lncRNA to: HOTAIR, CCAT2, GAS5, MALAT-1, UCA1. Badania, które oceniły poziom ekspresji lncRNA HOTAIR oraz CCAT2 w tkance zdrowej i nowotworowej, wykazały różne poziomy ekspresji u różnych autorów, co świadczy o tym, że ekspresja tego samego lncRNA może być zmienna osobniczo lub jest wynikiem błędów w przeprowadzonym badaniu.

Słowa kluczowe: IncRNA, rak jajnika, ekspresja, FIGO 


\section{INTRODUCTION}

$\mathrm{A}$ $\mathrm{n}$ important achievement of biology in the second half of the twentieth century was the understanding of the molecular processes underlying the expression of genetic information. Information created at that time seemed to be precise and completely describe the scheme of living organisms. The information was mainly focused on deoxyribonucleic acid (DNA) as an information carrier and proteins, i.e. the final product. Ribonucleic acid (RNA) molecules were attributed with the secondary role as an intermediary in protein biosynthesis. RNA is a polymer consisting of nucleotides composed of ribose, a phosphate residue, and one of four nitrogen bases: adenine, guanine, cytosine or uracil. Today, the knowledge about the functioning of RNA is much wider. It is known that RNA is not only a skeleton that binds proteins or an adapter that enables translation. The current state of knowledge warrants the conclusion that RNA is directly involved in the synthesis of proteins, and is a cofactor involved in many biochemical processes or affecting the structure of the genome ${ }^{(1)}$. Biology textbooks divide RNA into messenger (mRNA) and non-coding RNA (ncRNA). Among ncRNA, housekeeping RNA and regulatory RNA are distinguished. Housekeeping RNA includes rRNA, tRNA, snoRNA. Regulatory RNA is divided into short ncRNA ( $<200$ base pairs), long ncRNA (lncRNA) ( $>200$ base pairs), and very long ncRNA ( $>100,000$ base pairs). Short-coding RNA includes miRNA, siRNA, piRNA, tsRNA (Fig. 1) ${ }^{(2)}$. The amount of lncRNA outweighs the amount of short ncRNA. Most lncRNA is present in the nucleus and cytoplasm ${ }^{(3)}$. Recent research results indicate that lncRNA may be involved in the development of ovarian cancer. An increased level of lncRNA expression is associated with increased tumor size ${ }^{(4)}$ as well as lower predicted survival outcomes ${ }^{(5)}$. Studies reveal that the level of lncRNA expression is not dependent on the histological type ${ }^{(6)}$. The World Health Organization (2014) distinguishes the following histological types of ovarian cancer: serous cancer, mucous carcinoma, endometrioid cancer, clear cell carcinoma, transitional cell carcinoma, Brenner tumor, squamous cell carcinoma, mixed cancer, undifferentiated cancer, sarcoma carcinoma, and granulomatosis ${ }^{(7)}$.

\section{ETIOLOGY OF OVARIAN CANCER}

Over $95 \%$ of malignant ovarian tumors have epithelial origin. The most important risk factors include $B R C A 1$ and $B R C A 2$ mutation carriers, hereditary ovarian cancer syndromes, childlessness, hereditary ovarian and breast cancer syndromes, hereditary ovarian cancer, and familial

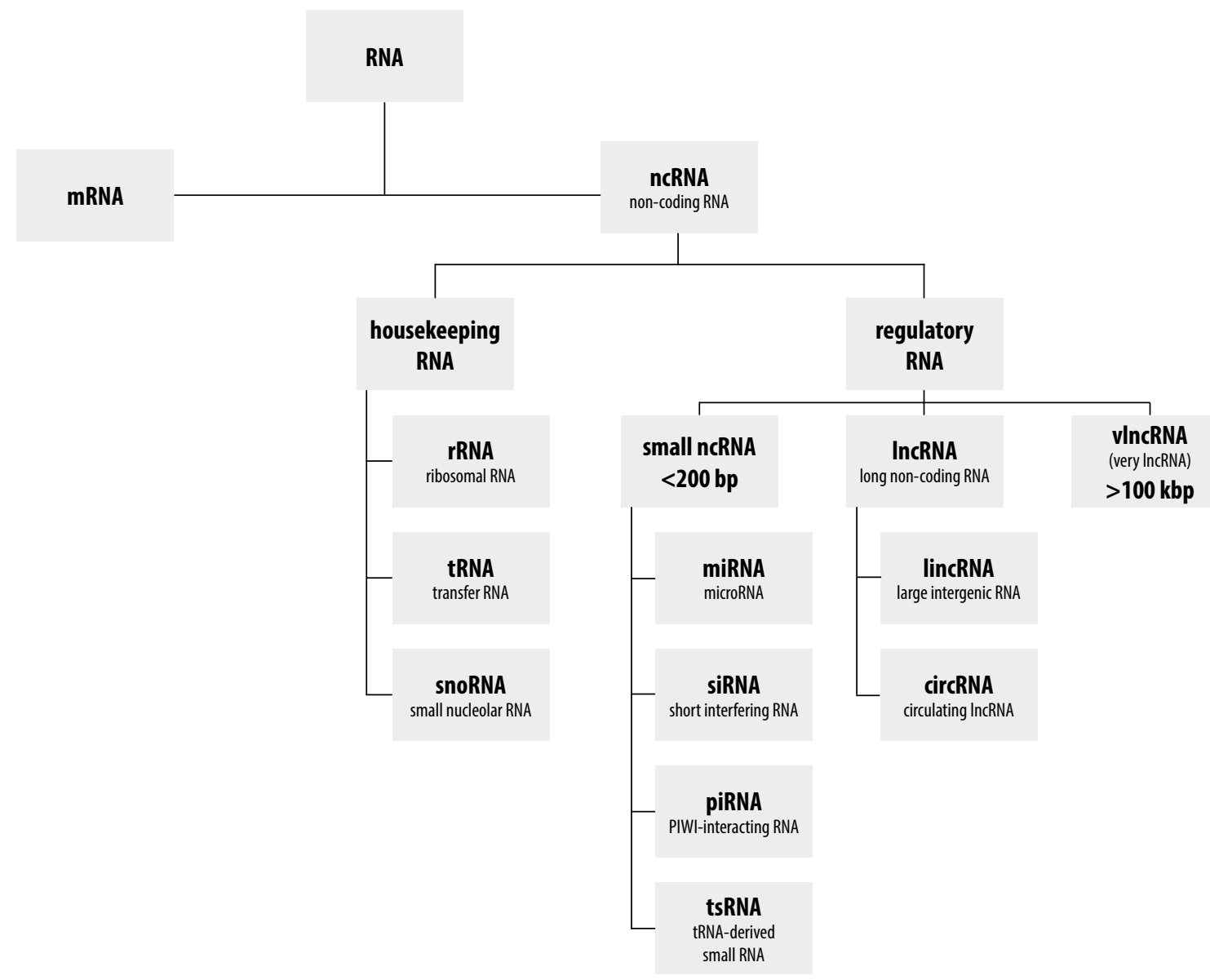

Fig. 1. RNA division ${ }^{(2)}$ 
occurrence of non-globular colorectal cancer. Factors that reduce the risk of ovarian cancer include hormonal contraception, fallopian tube occlusion, uterus excision, and breastfeeding ${ }^{(8)}$.

\section{HISTOLOGICAL TYPES OF OVARIAN CANCER AND THEIR CHARACTERISTICS}

Nowak-Markwitz and Spaczyński divide ovarian cancer into two types. Type I is characterized by a diagnosis at a less advanced stage, slow growth and low sensitivity to chemotherapy, and good prognosis. Type I comprises serous, endometrial, mucosal, clear cell carcinomas and Brenner cancers. Type II of ovarian cancer is diagnosed at stages III and IV. Type II is characterized by rapid growth and high sensitivity to chemotherapy, and poor prognosis. Type II comprises serous, endometrial, undifferentiated and sarcoma carcinomas $^{(9)}$ (Tab. 1).

\section{EFFECT OF LNCRNA EXPRESSION ON THE SURVIVAL OF PATIENTS WITH OVARIAN CANCER}

LncRNA does not have the translation potential due to the presence of multiple stop codons in mature transcripts ${ }^{(13)}$. However, the lack of protein coding and the absence of translation potential does not mean that lncRNA does not carry any information or perform any function ${ }^{(1)}$. The available literature does not contain precise information on the role of lncRNA in the process of protein biosynthesis and their exact function in the cancerous process. Studies conducted so far have focused on associations between increased expression of lncRNA and tumor development and its increased size or involvement in the proliferation and migration of tumor cells ${ }^{(14)}$. siRNA potentially contributes to lower expression of lncRNA NONRATT021972 as with other epigenetic mechanisms. Liu et al. (2016) observed that as a result of siRNA activity, the expression may be lowered by 0.5 in relation to the expression in which siRNA transfection was not applied ${ }^{(15)}$. In the majority of studies conducted to date, the exact impact of siRNA on the level of lncRNA expression has not been assessed, and the moment at which it is joined is not known. According to the literature data, some of them may have a prognostic value. Ning et al. (2018) conducted a meta-analysis to determine the impact of lncRNA expression on the survival of patients. A total of 15 studies evaluating 1,333 patients were included in the analysis. The results of the study predict a higher risk of death for patients with its increased level $(p>0.05)$. Another meta-analysis evaluated the effect of lncRNA expression on the survival time of patients based on its exact formula. A total of 14 studies were included in the study, with 1,276 participating patients. The results predict a higher risk of death in patients with its increased level $(p>0.05)$. The presented studies included the work of Xia et al. (2017) with the Kaplan-Meier curve, which presents the prognosis of survival of people at low and high level of lncRNA ZFAS1 over consecutive months. The KaplanMeier curve predicts that a high level of lncRNA may be associated with the death of $35 \%$ of patients 60 months after surgery $(p<0.05)$, and in the case of women with its low level, $40 \%$ of patients may die after approximately 65 months. Similar data was reported in the paper by Cheng et al. (2015). According to their results, 55\% of patients with a high level of lncRNA $A B 073614$ are expected to die after ca. 35 months $(p<0.05)$, and in the case of its low level, $50 \%$ of patients after 50 months are expected to die. The results obtained by Li et al. (2017) suggest a statistically significant difference between the predicted survival time of patients with low and high levels of lncRNA SPRY 4-IT1 expression. The death of $25 \%$ of patients with high levels of expression is expected after ca. 50 months, and approximately $55 \%$ with low levels after ca. 50 months $^{(5,16-21)}$. The results reported in the paper by Ning et al. (2018) indicate a very poor survival prognosis of patients who participated in the studies included in the meta-analysis.

\begin{tabular}{|c|c|c|}
\hline $\begin{array}{c}\text { Histological type } \\
\text { of ovarian cancer }\end{array}$ & Characteristics & Accompanying molecular changes \\
\hline Serous cancer & $\begin{array}{c}\text { The glandular epithelium differentiates towards the phenotype of oviduct } \\
\text { epithelial cells. In serous adenocarcinoma, a variety of glandular weaving } \\
\text { is found depending on the stage of cancer. }\end{array}$ & $\begin{array}{c}\text { Mutations in the KRAS gene (protooncogene Kristen } \\
\text { rat sarcoma viral oncogene homolog) or BRAF } \\
\text { (protooncogene B-Raf proto-oncogene) }\end{array}$ \\
\hline Endometrioid cancer & $\begin{array}{c}\text { The group of endometrioid ovarian tumors includes phenotypically equivalent } \\
\text { proliferations of all types of cancer that may develop in the endometrial mucosa. } \\
\text { In order to make an endometrial tumor diagnosis, no histological diagnosis } \\
\text { of endometriosis is necessary. }\end{array}$ & $\begin{array}{c}\text { Mutations of the PTEN gene (phosphatase, suppressor } \\
\text { protein), PIK3CA (gene coding the PI3K kinase catalytic } \\
\text { subunit), CTNNB1 (gene coding } \beta \text {-catenin) }\end{array}$ \\
\hline Mucosal tumor & $\begin{array}{c}\text { They have glandular epithelium in their woven cells, containing neutral } \\
\text { glucosamine (mucins) in the cytoplasm. Glandular epithelial cells are } \\
\text { phenotypically similar to cells of different mature epithelia producing mucus } \\
\text { (intestinal, glandular cells of the pylorus of the pyloric part). }\end{array}$ & $\begin{array}{c}\text { Mutations in the KRAS gene and HER2 overexpression } \\
\text { (superficial growth factor receptor) }\end{array}$ \\
\hline Clear cell carcinoma & $\begin{array}{c}\text { Dispatch through epithelium, cells which have a clear cytoplasm or sometimes } \\
\text { take on the hobnail appearance. }\end{array}$ & $\begin{array}{c}\text { Mutations in the TGF- } \beta \text { RII gene (transforming } \\
\text { the growth factor, receptor } \beta \text { II) }\end{array}$ \\
\hline Sarcoma & Non-epithelial origin derived from connective tissue & Mutations in TP53 \\
\hline $\begin{array}{c}\text { Undifferentiated ovarian } \\
\text { cancer }\end{array}$ & - & - \\
\hline
\end{tabular}

Tab. 1. Characteristics of different histological types of ovarian cancer $^{(10-12)}$ 


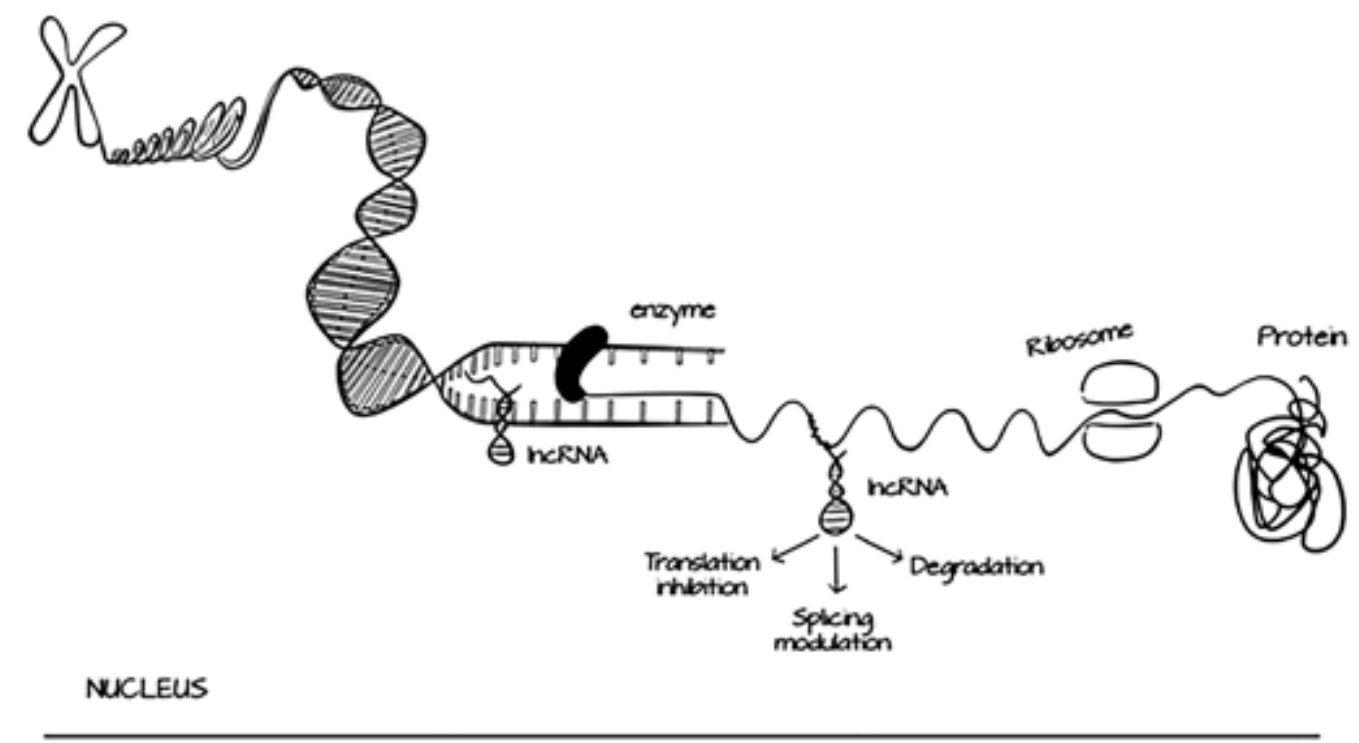

CYTOPLASM

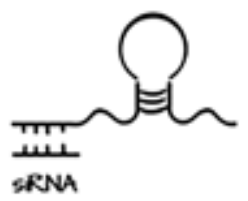

Fig. 2. Molecular function of $\operatorname{lncRNA^{(26,27)}}$

On the basis of only predicted values, it cannot be determined whether and to what extent an increased expression of lncRNA affects the survival time of patients ${ }^{(5)}$. Worku et al. (2017) in their study compiled 20 lncRNA and attributed the role they play in the cancer process. The analysis compared studies involving humans and animals, demonstrating that increased or decreased expression of ovarian cancer in lncRNA contributes to increased cell proliferation and migration, but there is no description of the underlying mechanism that is responsible for this observation ${ }^{(20)}$.

\section{ROLE OF InCRNA IN THE TRANSCRIPTION AND TRANSLATION PROCESS}

According to high school textbooks, the process of protein biosynthesis begins with the attachment of polymerase to the gene promoter and dehydration of the DNA double helix. RNA polymerase moves along the DNA strand and unravels it, adding subsequent nucleotides to the mRNA strand $^{(2,21)}$. In the next step of protein biosynthesis (translation), at first the ribosomal subunit attaches to the end of 5 ' mRNA, and the START (AUG) codon is attached with tRNA (transporting RNA). During the elongation and termination step, tRNA is carried by consecutive codons until the STOP codon is provided (at the termination stage) by tRNA to terminate the production of the polypeptide chain. In the biosynthesis process, miRNA proteins are responsible for regulating gene expression by joining this 6 nucleotide strand to mRNA and matching their nucleotides, as in the case to tRNA and mRNA, provided that the degradation of the mRNA strand is an effect of miRNA attachment to mRNA. When the complementarity is incomplete, the process of protein biosynthesis is blocked. siRNA is also responsible for the silencing of gene expression. siRNA at the time of connection with the complementary strand of mRNA contributes to the fact that the mRNA strands are cleaved, which prevents the formation of coded protein ${ }^{(21,22)}$. At the time when the splicing of intronic regions takes place in the transcription process, after it ends there may be degradation of genetic material by the enzyme or protein that has been synthesized. The RNA types mentioned in school textbooks include ribosomal RNA (rRNA), whose molecules are a component of ribosomes structures where proteins are synthesized, and small nuclear RNA (snRNA), which are involved in the pre-mRNA assembly process the main stage of maturation - transforming the primary transcript of genes encoding mRNA proteins. School textbooks do not describe the exact mechanism of ribosome formation from rRNA, and how it goes into their construction. According to the data reported by de la Cruz et al. (1999) DNA, as a result of rRNA transcription, leads to the formation of mRNA of which the polypeptide chain is biosynthesized, from which ribosomes are then biosynthesized ${ }^{(23)}$. The literature data indicates that the mechanism of protein biosynthesis is in fact more complicated, and more types of RNA are involved in it. Numerous studies were published, attempting to describe the functions of lncRNA in this process. Osielska and Jagodziński (2018) 
indicate that the epigenetic mechanism of lncRNA action depends on its potential attachment to tRNA in the translation process, however, their study shows that the attachment of IncRNA occurs when tRNA is connected to three ribosomes ${ }^{(2)}$. Usually, one ribosome is involved in the translation process ${ }^{(21)}$. Carpenter (2016) argues that lncRNA may play a role in the transcription process. The author does not discuss whether lncRNA is transcribed into mRNA and is a non-coding fragment of an exon that is included in the process of translation into protein biosynthesis or is an intron not transmitted to mRNA and under the influence of polymerase the IncRNA section is separated from the mRNA fragment, and IncRNA thus created participates in epigenetic mechanisms ${ }^{(24)}$. mRNA may be reverse-transcribed, resulting in the re-formation of DNA that can be stored in the form of chromosomes by wrapping into histones. Despite the lack of accurate information on whether lncRNA is prescribed for mRNA and is subject to the transcription and translation process like the other genes, or the translation process takes place, lncRNA is an intron and is excreted in the transcription process. Based on the information contained in the gene bank, it can be assumed that lncRNA ultimately undergoes reverse transcription and is found on one of the chromosomes ${ }^{(24,25)}$ (Fig. 2).

\section{CHARACTERISTICS OF InCRNA IN OVARIAN CANCER}

HOTAIR is located on chromosome 12. According to the Gene Bank database, even though it is a non-coding region, no protein products are attributed to it, and the effect of increased HOTAIR IncRNA expression is the binding of lysine demethylase (LSD 1) and repulsive complex 2 Polycomb (PRC2) and it serves as scaffolding to connect these regulators to the HOXD gene cluster. The available literature lacks data on the method of binding of the above-mentioned compounds.

MALAT is located on chromosome 11. According to Gene Bank, it controls the transcription process and is stored in the nucleus, where it forms a framework for ribonucleoprotein complexes (which include miRNA), which are responsible for blocking the translation process. It can be assumed that this segment is subject to the process of splicing before the translation process, due to the formation of ribonucleoprotein complexes. The available literature lacks a description of the exact mechanism that leads to the incorporation of IncRNA MALAT into these complexes.

GAS5 is located on chromosome 6, and the product of this gene is lncRNA. According to Gen Cards, the component of this lncRNA is snoRNA.

HOXA11 according to Gene Bank, is located on chromosome 6 and the result of its action is the impact on the rate of expression of other chromosome 6 genes, the product of which is a protein. According to the Gen Cards data HOXA11 encodes a protein, but there are no literature
There is no data about the functions of some lncRNA in the Gene Bank, including ANRIL, UCA1, CCAT2, BC200, TUG1, LNCRSR, RAD51-AS1, DARS-AS1, LSINCT5, AFAP-1AS1, lncSOX4, SNHG20(28) (tab. 2).

\section{METHODOLOGY}

The PubMed database was systematically searched to identify studies that assessed the role of lncRNA in ovarian cancer. The effect of lncRNA expression on tumor size was evaluated. The following phrases were searched: ovarian cancer lncRNA (350 publications), lncRNA ovarian cancer review (36 publications), IncRNA ovarian cancer meta-analysis (11 publications), MALAT lncRNA ovarian cancer (4 publications), lncRNA ovarian cancer H19 (32 publications), lncRNA ovarian cancer HOTAIR (23 publications), lncRNA ovarian cancer HOST2 (2 publications), lncRNA ovarian cancer UCA1 (15 publications), lncRNA ovarian cancer PVT1 (1 publication), lncRNA SNHG20 ovarian cancer (3 publication), and IncRNA RAD51-AS1 ovarian cancer (1 publication), covering a period from October 15 , 2018 to 22 August, 2020. The review included studies conducted among women with ovarian cancer that included information about the size of the study and control groups, which consisted of tissue samples collected from women with cancer involving sites that were not covered by the disease process, and the level of lncRNA expression in cancer tissue and healthy tissue. The review excluded studies conducted on animals and humans which provided no information about the size of the study group and the level of lncRNA expression. Also, the review did not include studies in which the control group consisted of women with benign ovarian cancer or the study group comprised patients with varying degrees of sensitivity to cisplatin.

\section{SUMMARY}

Previously conducted reviews of studies and meta-analyses concerned with the assessment of the role of lncRNA in ovarian cancer did not comprise all studies, and there are no exact data on the impact of different lncRNA on tumor size. The most frequently studied lncRNA included HOTAIR, CCAT2, GAS5, MALAT, MALAT-1, UCA1. In the studies carried out to date, the differences in IncRNA expression in healthy and cancerous tissue were typically evaluated without assessing the difference between IncRNA expression in the healthy and cancerous tissues with varying FIGO (International Federation of Gynecology and Obstetrics) stages. The results of eleven studies indicate that increased expression of lncRNA contributes to tumor growth $(p<0.05)$, and the findings obtained in eight studies indicate that increased lncRNA expression is related to metastases. Research carried out to date lacks accurate data that would indicate to what extent increased or decreased expression of lncRNA increases the size of the tumor. Studies evaluating the expression level in the HOTAIR or CCAT2 lncRNA gene in 


\begin{tabular}{|c|c|c|c|c|c|c|}
\hline 竧 & 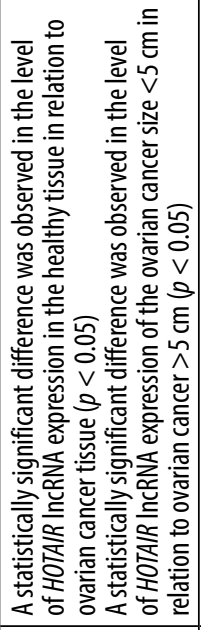 & 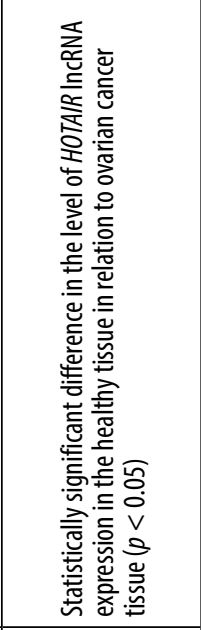 & 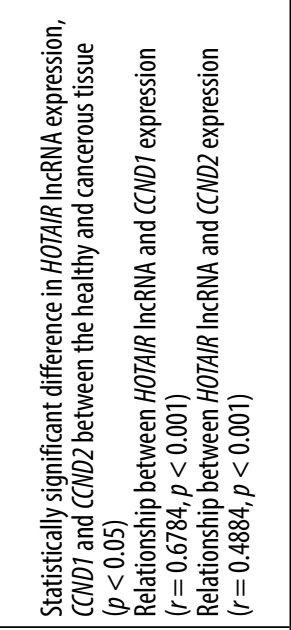 & 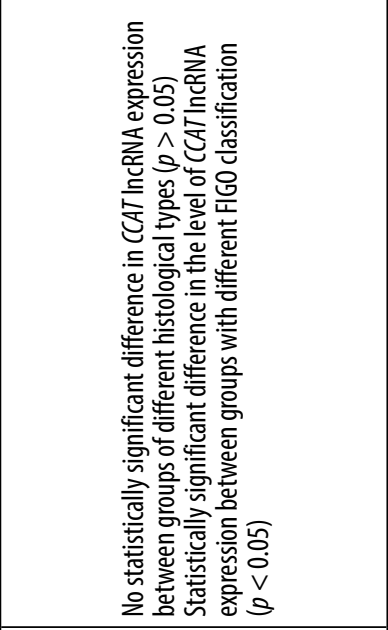 & 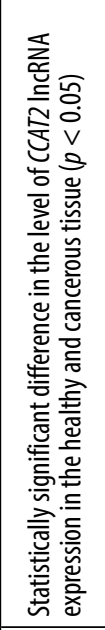 & 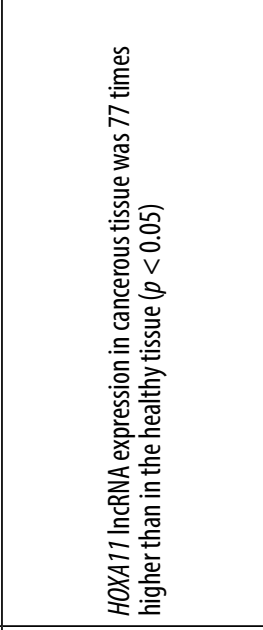 \\
\hline 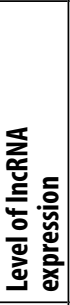 & 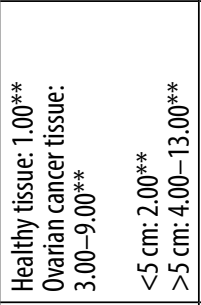 & 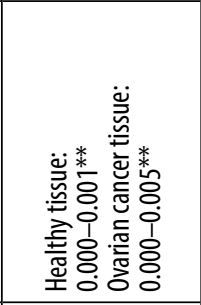 & 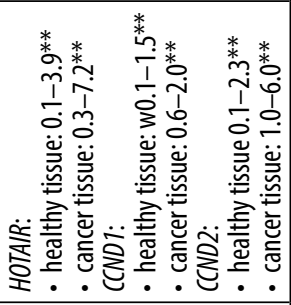 & 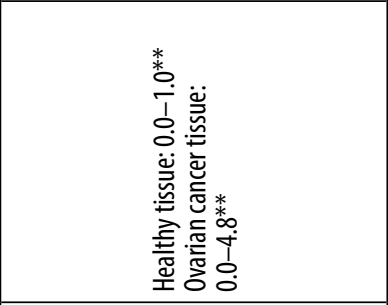 & 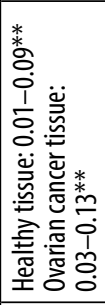 & 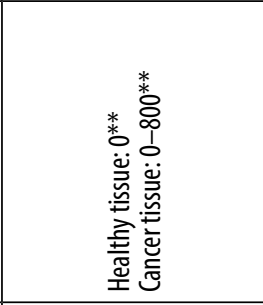 \\
\hline 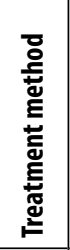 & 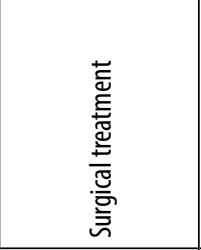 & 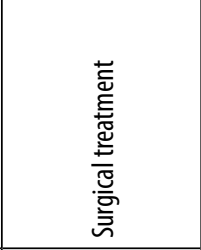 & 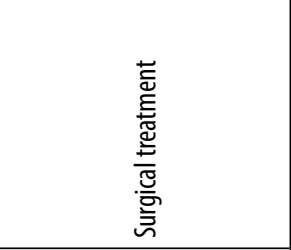 & 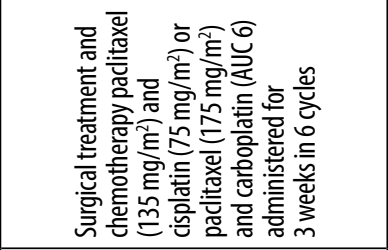 & 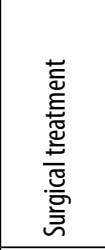 & 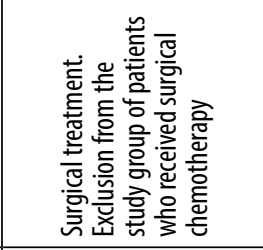 \\
\hline 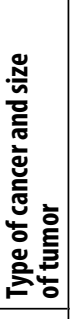 & 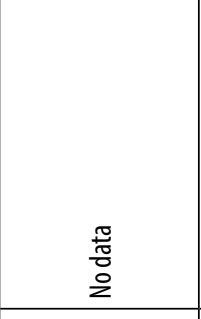 & 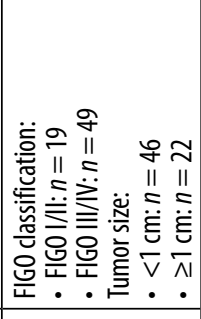 & 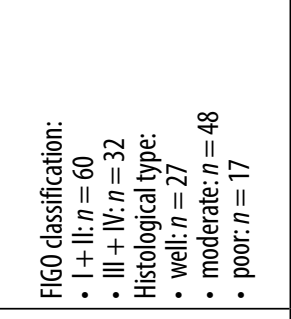 & 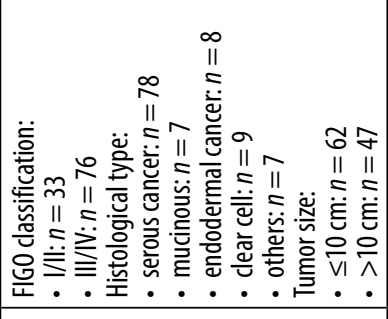 & $\begin{array}{l}\frac{\pi}{5} \\
\frac{\pi}{0} \\
20 \\
2\end{array}$ & 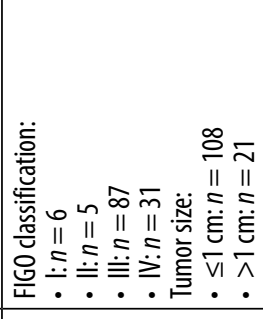 \\
\hline gั & 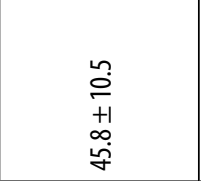 & 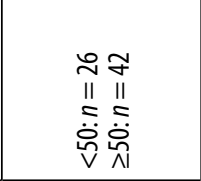 & 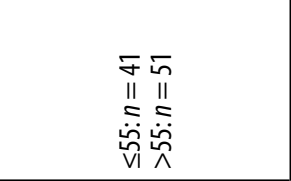 & 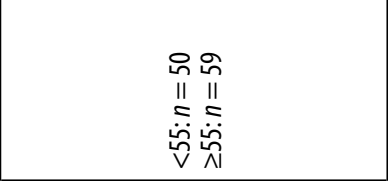 & 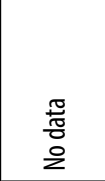 & 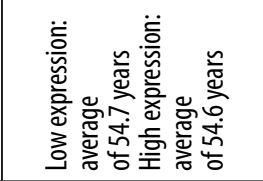 \\
\hline 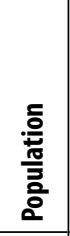 & 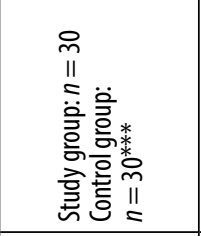 & 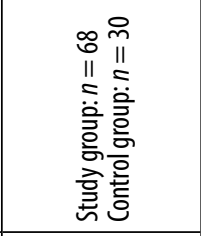 & 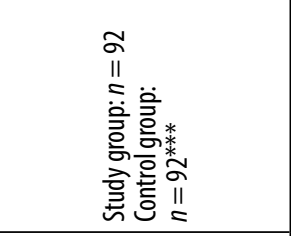 & 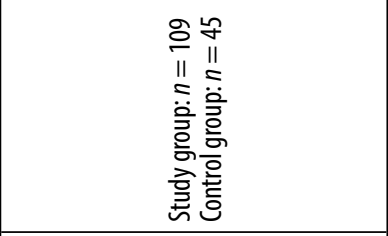 & 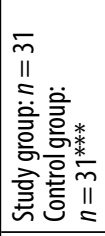 & 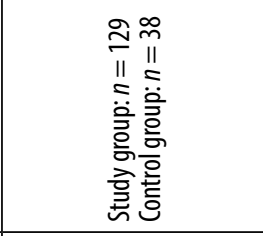 \\
\hline 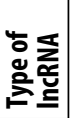 & 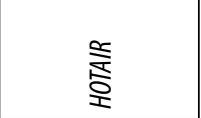 & 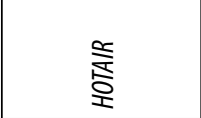 & 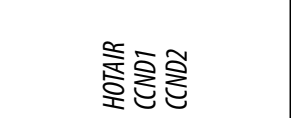 & 芯 & 芯 & i \\
\hline 京 & 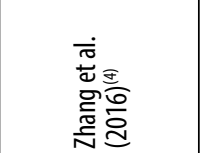 & 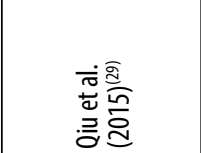 & 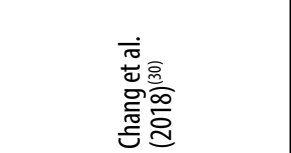 & 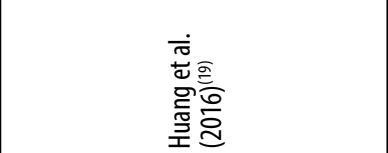 & 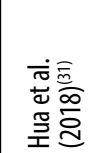 & 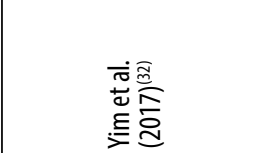 \\
\hline
\end{tabular}




\begin{tabular}{|c|c|c|c|c|c|c|c|}
\hline 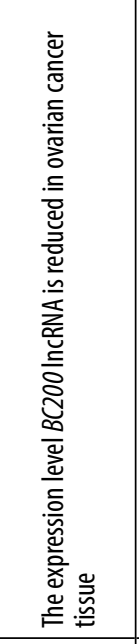 & 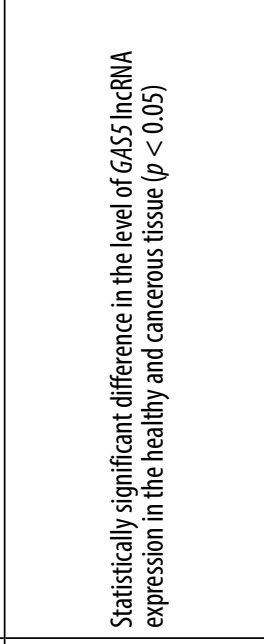 & 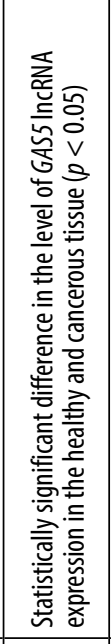 & 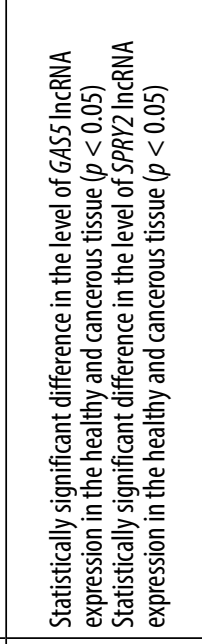 & 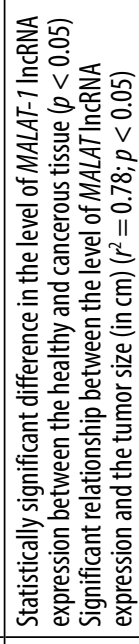 & 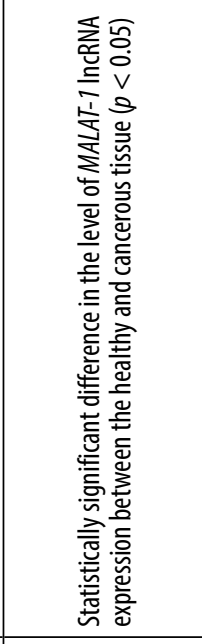 & 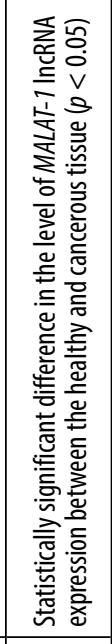 & 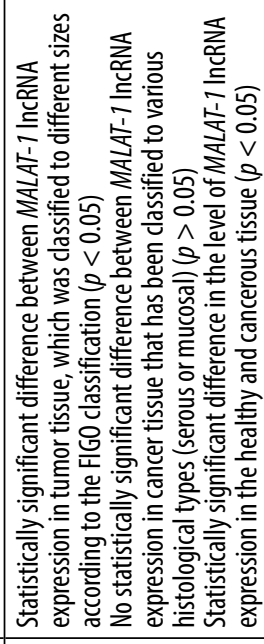 \\
\hline 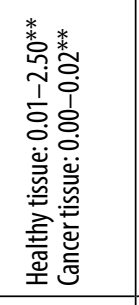 & 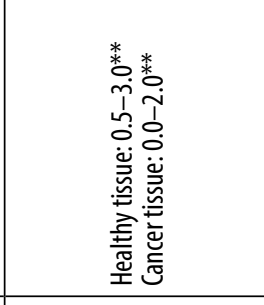 & 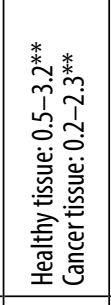 & 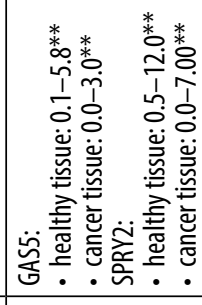 & 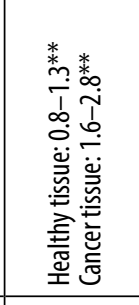 & 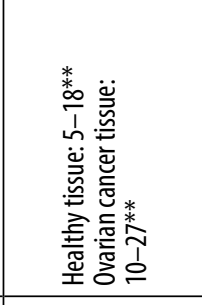 & 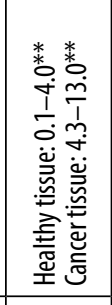 & 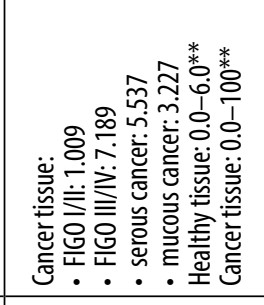 \\
\hline $\begin{array}{l}\frac{5}{5} \\
\text { 苋 } \\
2 \\
\end{array}$ & 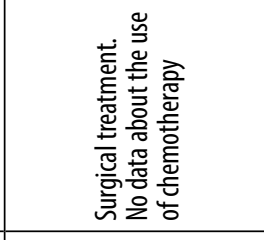 & 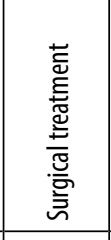 & 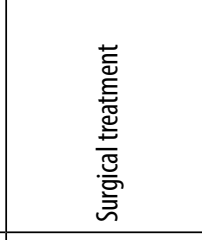 & 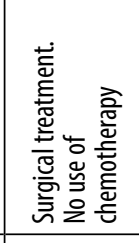 & 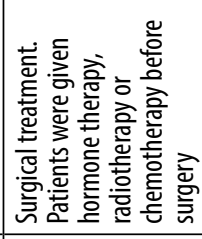 & 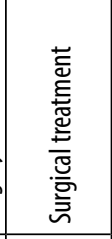 & 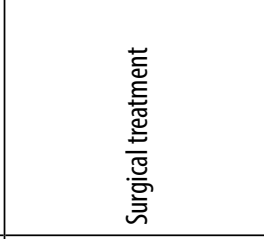 \\
\hline 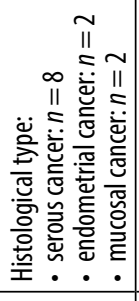 & 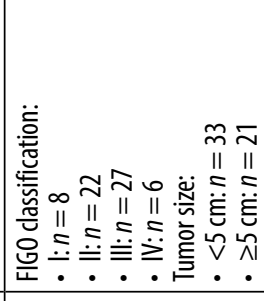 & $\begin{array}{l}\frac{\pi}{0} \\
\frac{\pi}{0} \\
0 \\
\end{array}$ & 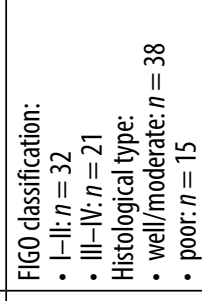 & $\begin{array}{l}\frac{\pi}{0} \\
\frac{\pi}{0} \\
2 \\
\end{array}$ & $\begin{array}{l}\frac{\pi}{2} \\
\frac{\pi}{0} \\
2 \\
2\end{array}$ & 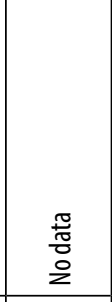 & 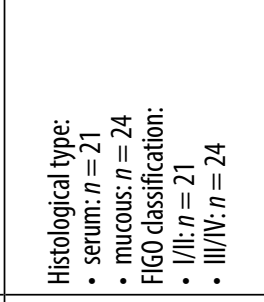 \\
\hline $\begin{array}{l}\frac{0}{10} \\
\text { 莟 } \\
2 \\
\end{array}$ & 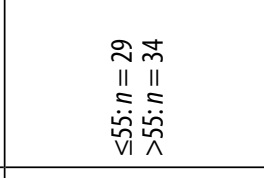 & $\begin{array}{l}\frac{\pi}{5} \\
\text { 퓽 } \\
2 \\
\end{array}$ & 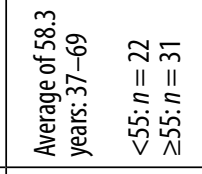 & 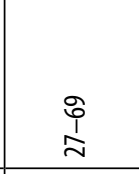 & $\begin{array}{l}\frac{\pi}{\pi} \\
\frac{\pi}{0} \\
2 \\
\end{array}$ & $\begin{array}{l}\frac{\pi}{5} \\
\text { T⿱艹 } \\
2 \\
2\end{array}$ & 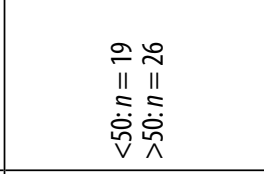 \\
\hline 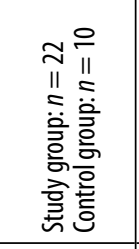 & 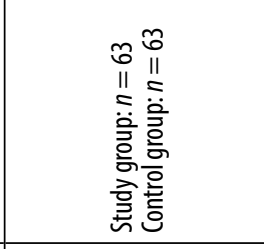 & 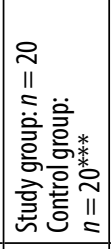 & 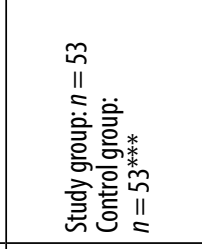 & 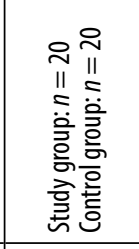 & 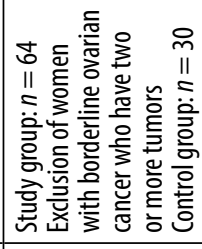 & 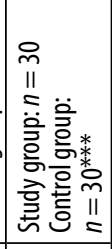 & 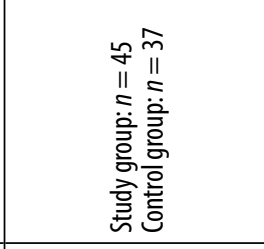 \\
\hline ¿্ర్రి & 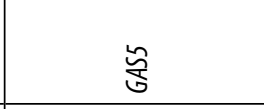 & 慈 & 岕悹 & 文 & 文 & $\underset{⿱ 亠}{\frac{1}{3}}$ & $\underset{⿱ 亠}{\frac{1}{3}}$ \\
\hline 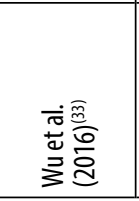 & 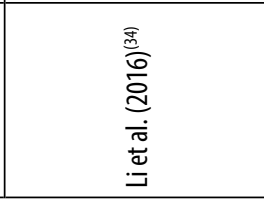 & 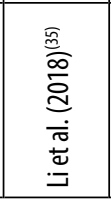 & 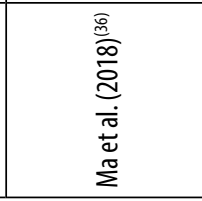 & 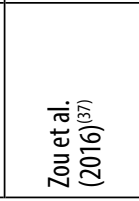 & 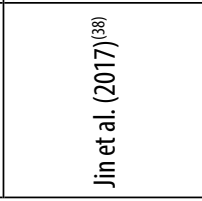 & 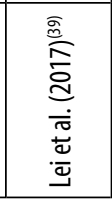 & 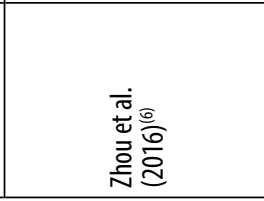 \\
\hline
\end{tabular}




\begin{tabular}{|c|c|c|c|}
\hline 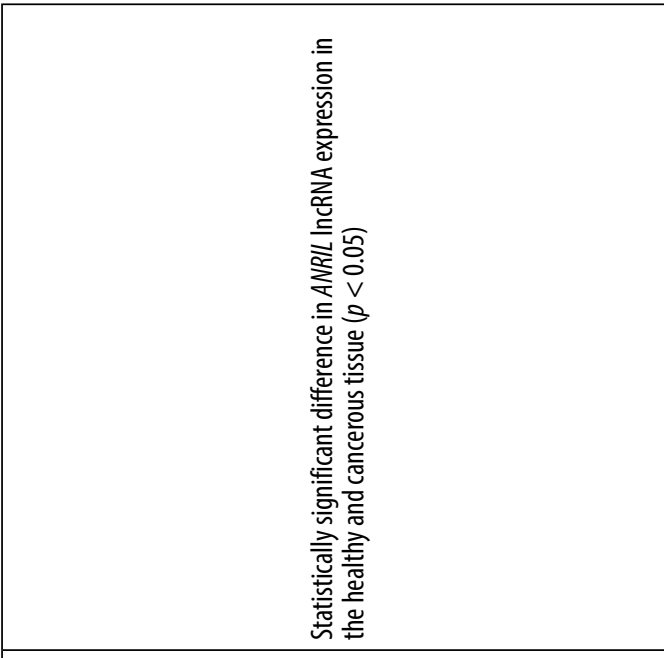 & 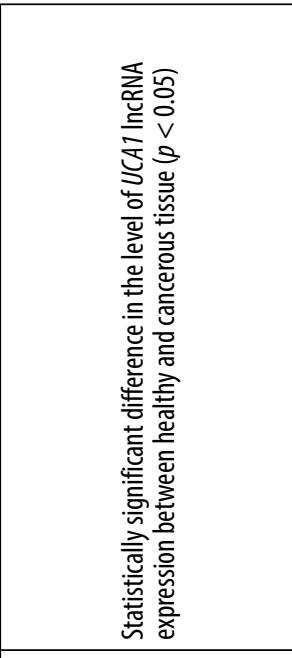 & 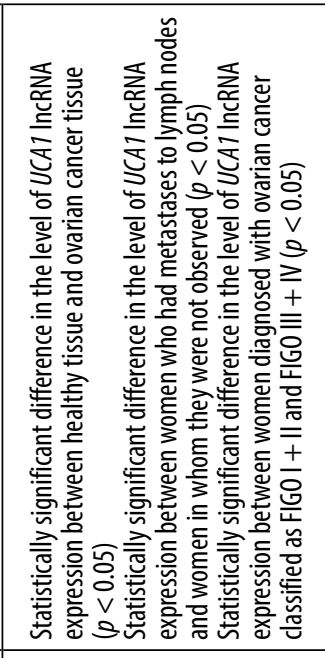 & 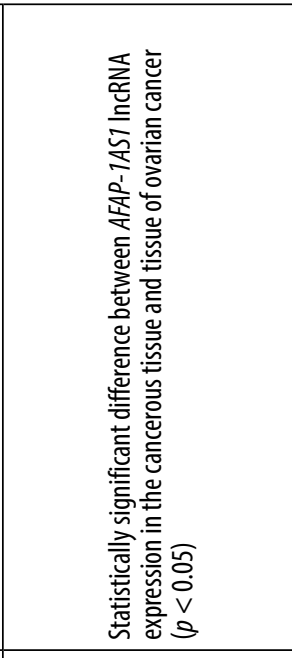 \\
\hline 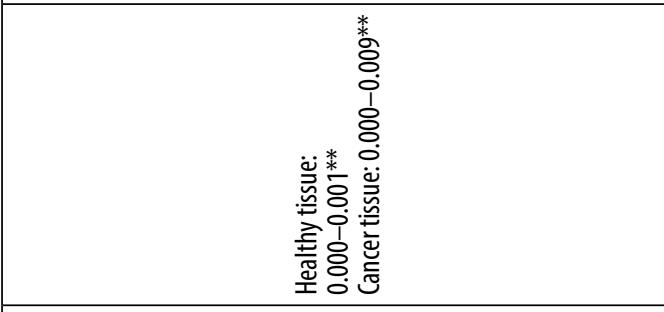 & 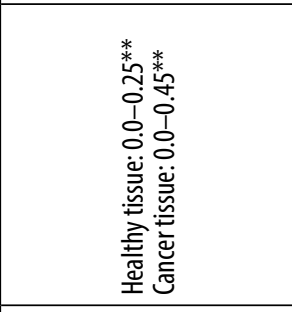 & 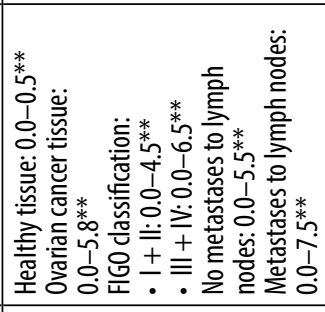 & 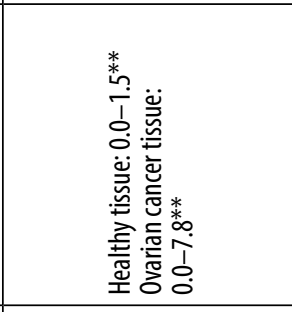 \\
\hline 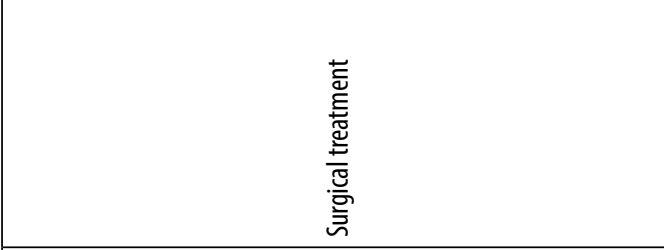 & 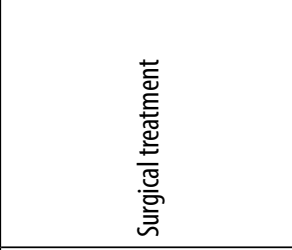 & 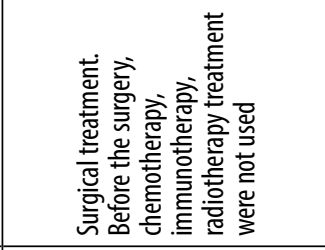 & 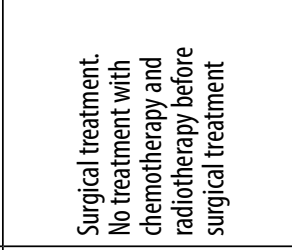 \\
\hline 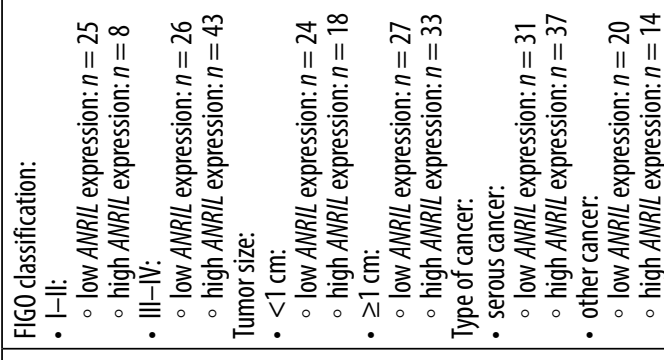 & 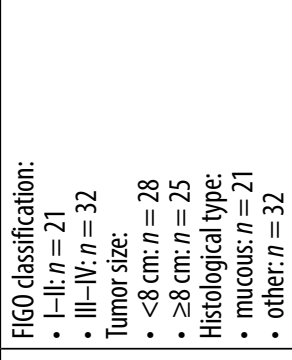 & 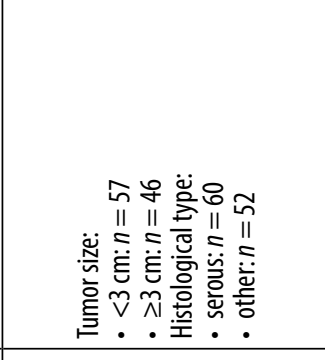 & 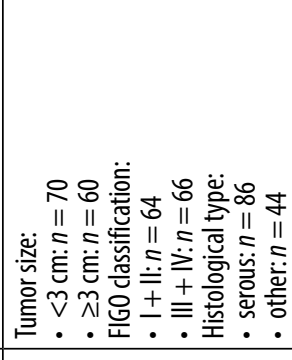 \\
\hline 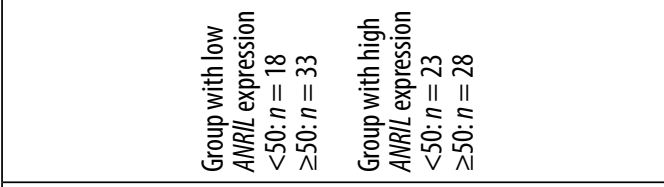 & 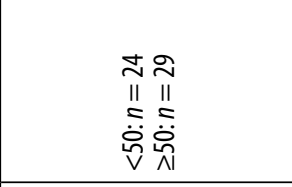 & 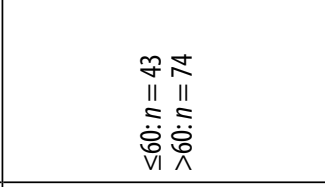 & 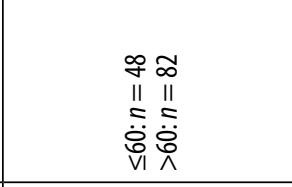 \\
\hline 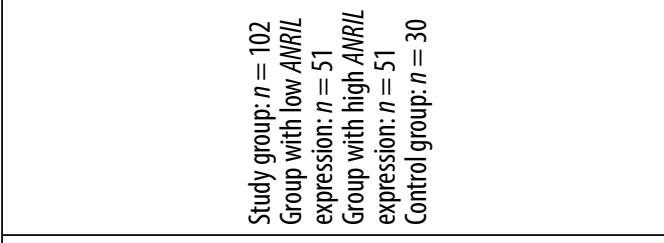 & 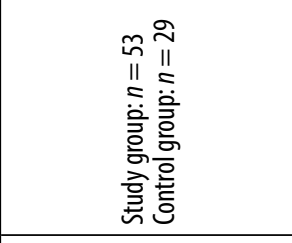 & 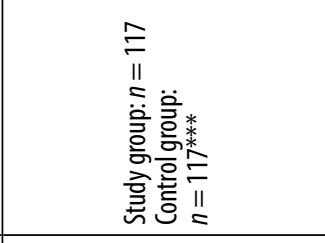 & 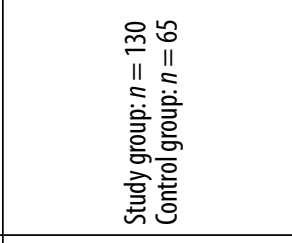 \\
\hline 旁 & $\bar{s}$ & $\bar{s}$ & $\begin{array}{l}\bar{y} \\
\frac{\pi}{1} \\
\frac{1}{4} \\
\end{array}$ \\
\hline 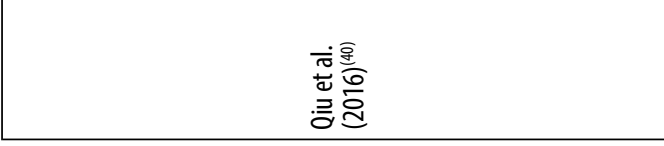 & 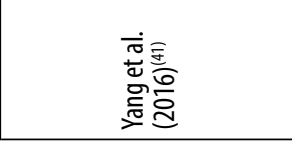 & 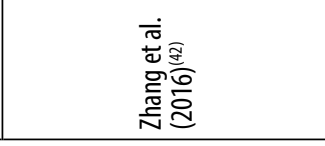 & 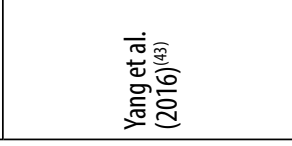 \\
\hline
\end{tabular}




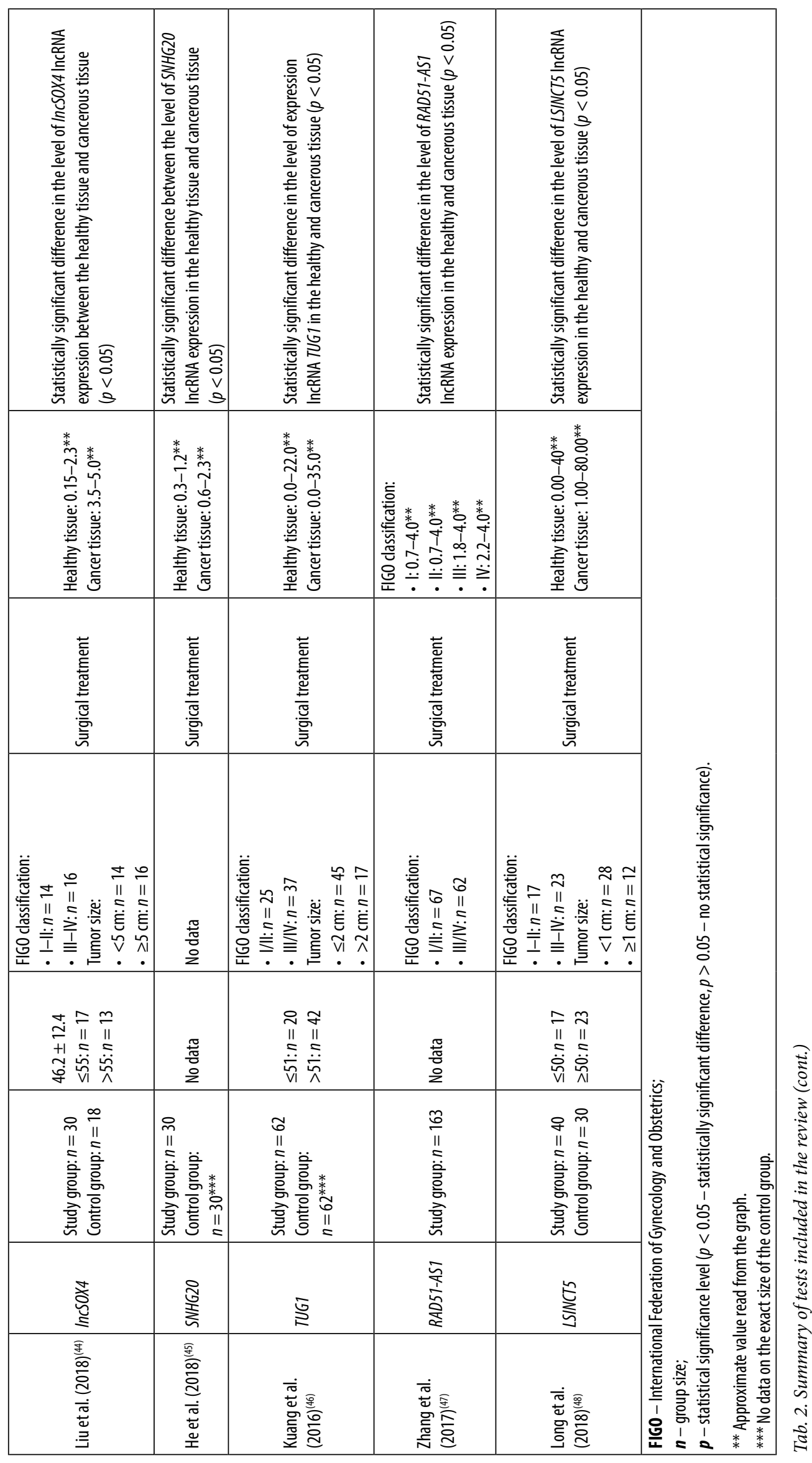


ovarian cancer tissue and healthy tissue showed varying levels of expression in papers published by different authors, indicating that the expression of the same lncRNA can be variable individually or is attributable to study errors. Currently, there is no cytotoxic drug with an effect on lncRNA available on the market.

\section{Conflict of interest}

The author declares no potential conflicts of interest with respect to the research, authorship, and/or publication of this article.

\section{References}

1. Tyczewska A, Figlerowicz M: Nowe oblicze „świata RNA”. Nauka 2009; 2: 93-109.

2. Osielska MA, Jagodziński PP: Long non-coding RNA as potential biomarkers in non-small-cell lung cancer: what do we know so far? Biomed Pharmacother 2018; 101: 322-333.

3. Zhao M, Qiu Y, Yang B et al.: Long non-coding RNAs involved in gynecological cancer. Int J Gynecol Cancer 2014; 24: 1140-1145.

4. Zhang $\mathrm{Z}$, Cheng J, Wu Y et al.: LncRNA HOTAIR controls the expression of Rab22a by sponging miR-373 in ovarian cancer. Mol Med Rep 2016; 14: 2465-2472.

5. Ning L, Hu YC, Wang S et al.: Altered long noncoding RNAs and survival outcomes in ovarian cancer: a systematic review and meta-analysis (PRISMA Compliant). Medicine (Baltimore) 2018; 97: e11481.

6. Zhou $\mathrm{Y}, \mathrm{Xu} \mathrm{X}, \mathrm{Lv} \mathrm{H}$ et al.: The long noncoding RNA MALAT-1 is highly expressed in ovarian cancer and induces cell growth and migration. PLoS One 2016; 11: e0155250.

7. Bednarek-Rajewska K, Korski K, Bręborowicz J: Rak jajnika. Available from: http://med.pol-pat.pl/pliki/files/standardy_ pdf/6.5._jajnik.pdf [cited: 5 June 2019].

8. Kornafel J, Mądry R (eds.): Nowotwory kobiecego układu płciowego. 2013. In: Zalecenia postępowania diagnostyczno-terapeutycznego w nowotworach złośliwych - 2019 rok. Available from: http:// onkologia.zalecenia.med.pl/pdf/zalecenia_PTOK_tom1_06_Nowotwory_kobiecego_ukladu_plciowego_20130301.pdf

9. Nowak-Markwitz E, Spaczyński M: Rak jajnika - nowe spojrzenie na pochodzenie i histogenezę. Ginekol Pol 2012; 83: 454-457.

10. Wcisło G, Szczylik C (eds.): Rak jajnika. Patobiologia, diagnostyka i przegląd współczesnych metod leczenia. Termedia Wydawnictwa Medyczne, Poznań 2011.

11. Kaldawy A, Segev Y, Lavie O et al.: Low-grade serous ovarian cancer: a review. Gynecol Oncol 2016; 143: 433-438.

12. Kujawa KA, Lisowska KM: Rak jajnika - od biologii do kliniki. Postepy Hig Med Dosw (online) 2015; 69: 1275-1290.

13. Zhao CN, Mao YM, Liu LN et al.: Emerging role of lncRNAs in systemic lupus erythematosus. Biomed Pharmacother 2018; 106: 584-592.

14. Nikpayam E, Tasharrofi B, Sarrafzadeh $S$ et al.: The role of long non-coding RNAs in ovarian cancer. Iran Biomed J 2017; 21: 3-15.

15. Liu S, Zou L, Xie J et al.: LncRNA NONRATT021972 siRNA regulates neuropathic pain behaviors in type 2 diabetic rats through the $\mathrm{P} 2 \mathrm{X}_{7}$ receptor in dorsal root ganglia. Mol Brain 2016; 9: 44.

16. $\mathrm{Li} \mathrm{H}, \mathrm{Liu} \mathrm{C}, \mathrm{Lu} \mathrm{Z}$ et al.: Upregulation of the long non-coding RNA SPRY4-IT1 indicates a poor prognosis and promotes tumorigenesis in ovarian cancer. Biomed Pharmacother 2017; 88: 529-534.

17. Xia B, Hou $\mathrm{Y}$, Chen $\mathrm{H}$ et al.: Long non-coding RNA ZFAS1 interacts with miR-150-5p to regulate $\mathrm{Sp} 1$ expression and ovarian cancer cell malignancy. Oncotarget 2017; 8:19534-19546.

18. Cheng Z, Guo J, Chen L et al.: A long noncoding RNA AB073614 promotes tumorigenesis and predicts poor prognosis in ovarian cancer. Oncotarget 2015; 6: 25381-25389.
19. Huang S, Qing C, Huang $Z$ et al.: The long non-coding RNA CCAT2 is up-regulated in ovarian cancer and associated with poor prognosis. Diagn Pathol 2016; 11: 49.

20. Worku T, Bhattarai D, Ayers D et al.: Long non-coding RNAs: the new horizon of gene regulation in ovarian cancer. Cell Physiol Biochem 2017; 44: 948-966.

21. Dubert F, Jurgowiak $M$, Marko-Worłowska $M$ et al.: Biologia na czasie 3. Podręcznik dla liceum ogólnokształcącego i technikum. Nowa Era, Warszawa 2017.

22. Jorde LB, Carey JC, Bamshad MJ: Genetyka medyczna. Elsevier Urban \& Partner, Wrocław 2013.

23. de la Cruz J, Kressler D, Linder P: Unwinding RNA in Saccharomyces cerevisiae: DEAD-box proteins and related families. Trends Biochem Sci 1999; 24: 192-198.

24. Carpenter S: Determining the function of long noncoding RNA in innate immunity. Methods Mol Biol 2016; 1390: 183-195.

25. Chen LL: Linking long noncoding RNA localization and function. Trends Biochem Sci 2016; 41: 761-772.

26. Dong P, Xiong Y, Yue J et al.: Long non-coding RNA NEAT1: a novel target for diagnosis and therapy in human tumors. Front Genet 2018; 9: 471.

27. Salehi S, Taheri MN, Azarpira N et al.: State of the art technologies to explore long non-coding RNAs in cancer. J Cell Mol Med 2017; 21: 3120-3140.

28. National Center for Biotechnology Information, U.S. National Library of Medicine: Gene. Available from: https://www.ncbi. nlm.nih.gov/gene/ [cited: 6 December 2018].

29. Qiu JJ, Wang Y, Ding JX et al.: The long non-coding RNA HOTAIR promotes the proliferation of serous ovarian cancer cells through the regulation of cell cycle arrest and apoptosis. Exp Cell Res 2015; 333: 238-248.

30. Chang L, Guo R, Yuan Z et al.: LncRNA HOTAIR regulates CCND1 and CCND2 expression by sponging miR-206 in ovarian cancer. Cell Physiol Biochem 2018; 49: 1289-1303.

31. Hua F, Li CH, Chen XG et al.: Long noncoding RNA CCAT2 knockdown suppresses tumorous progression by sponging miR-424 in epithelial ovarian cancer. Oncol Res 2018; 26: 241-247.

32. Yim GW, Kim HJ, Kim LK et al.: Long non-coding RNA HOXA11 antisense promotes cell proliferation and invasion and predicts patient prognosis in serous ovarian cancer. Cancer Res Treat 2017; 49: 656-668.

33. Wu DI, Wang T, Ren C et al.: Downregulation of BC200 in ovarian cancer contributes to cancer cell proliferation and chemoresistance to carboplatin. Oncol Lett 2016; 11: 1189-1194.

34. Li J, Huang H, Li Y et al.: Decreased expression of long non-coding RNA GAS5 promotes cell proliferation, migration and invasion, and indicates a poor prognosis in ovarian cancer. Oncol Rep 2016; 36: 3241-3250.

35. Li J, Yang C, Li Y et al.: LncRNA GAS5 suppresses ovarian cancer by inducing inflammasome formation. Biosci Rep 2018; 38: BSR20171150.

36. Ma N, Li S, Zhang Q et al.: Long non-coding RNA GAS5 inhibits ovarian cancer cell proliferation via the control of microRNA-21 and SPRY2 expression. Exp Ther Med 2018; 16: 73-82.

37. Zou A, Liu R, Wu X: Long non-coding RNA MALAT1 is up-regulated in ovarian cancer tissue and promotes SK-OV-3 cell proliferation and invasion. Neoplasma 2016; 63: 865-872.

38. Jin Y, Feng SJ, Qiu S et al.: LncRNA MALAT1 promotes proliferation and metastasis in epithelial ovarian cancer via the PI3K-AKT pathway. Eur Rev Med Pharmacol Sci 2017; 21: 3176-3184.

39. Lei R, Xue M, Zhang L et al.: Long noncoding RNA MALAT1regulated microRNA 506 modulates ovarian cancer growth by targeting iASPP. Onco Targets Ther 2017; 10: 35-46.

40. Qiu JJ, Wang Y, Liu YL et al.: The long non-coding RNA ANRIL promotes proliferation and cell cycle progression and inhibits apoptosis and senescence in epithelial ovarian cancer. Oncotarget 2016; 7: 32478-32492. 
41. Yang Y, Jiang Y, Wan Y et al.: UCA1 functions as a competing endogenous RNA to suppress epithelial ovarian cancer metastasis. Tumour Biol 2016; 37: 10633-10641.

42. Zhang L, Cao X, Zhang L et al.: UCA1 overexpression predicts clinical outcome of patients with ovarian cancer receiving adjuvant chemotherapy. Cancer Chemother Pharmacol 2016; 77: 629-634.

43. Yang SL, Lin RX, Si LH et al.: Expression and functional role of long non-coding RNA AFAP1-AS1 in ovarian cancer. Eur Rev Med Pharmacol Sci 2016; 20: 5107-5112.

44. Liu Y, Wang Y, Yao D et al.: LncSOX4 serves an oncogenic role in the tumorigenesis of epithelial ovarian cancer by promoting cell proliferation and inhibiting apoptosis. Mol Med Rep 2018; 17: 8282-8288.

45. He S, Zhao Y, Wang X et al.: Up-regulation of long non-coding RNA SNHG20 promotes ovarian cancer progression via Wnt/ $\beta$ catenin signaling. Biosci Rep 2018; 38: BSR20170681.
46. Kuang D, Zhang X, Hua S et al.: Long non-coding RNA TUG1 regulates ovarian cancer proliferation and metastasis via affecting epithelial-mesenchymal transition. Exp Mol Pathol 2016; 101: 267-273.

47. Zhang X, Liu G, Qiu J et al.: E2F1-regulated long non-coding RNA RAD51-AS1 promotes cell cycle progression, inhibits apoptosis and predicts poor prognosis in epithelial ovarian cancer. Sci Rep 2017; 7: 4469.

48. Long X, Li L, Zhou Q et al.: Long non-coding RNA LSINCT5 promotes ovarian cancer cell proliferation, migration and invasion by disrupting the CXCL12/CXCR4 signalling axis. Oncol Lett 2018; 15: 7200-7206. 